\title{
38. FUNGII IN CORE 9, SITE 372, DSDP LEG 42A, MEDITERRANEAN SEA
}

\author{
H. E. Franz, Geologisches Institut, Eidg. Technische Hochschule, Zurich, Switzerland \\ M. Cita, Instituto di Geologia, University di Milano, Milano, Italy \\ J. Neher, Geologisches Institut, Eidg. Technische Hochschule, Zurich, Switzerland \\ K. J. Hsü, Geologisches Institut, Eidg. Technische Hochschule, Zurich, Switzerland
}

\section{INTRODUCTION}

Site 372 is located on the Menorca margin near the edge of the Balearic Abyssal Plain. The hole penetrated 885 meters and was terminated in Burdigalian sediments. Core 9 consists of Messinian sediments lying unconformably on Serravallian hemipelagic marls.

The Messinian sediments directly above consist of well-laminated marls. The varve-like laminae are a few millimeters in thickness. The marls yielded marine planktonic and benthic foraminifers and calcareous nannofossils. The lithology and micropaleontology of the laminated and varve-like sediments are described in the Site Report, Chapter 3. Their significance and environment of deposition are discussed in Cita et al. (this volume).

In the white laminae of the varve-like sediments, Cita discovered microfossils of unknown affinity. These were subsequently identified as fungii remains. Samples were sent to Zurich for detailed scanning electron microscopy. This report describes and illustrates this rare fossil occurrence.

\section{SEM STUDY OF SPHERULITES AND THEIR ASSIGNMENT TO THE ACTINOMYCETES}

In the white laminae of the varve-like sediments of Section 372-9-2 very small rounded objects were detected by scanning electron microscopy in the hollow spaces. These objects resemble sporangia of Recent fungi. Here we briefly describe these spherules and compare them with similar fructifications of Actinomycetes.

Plate 1 shows examples of the spherulites in various magnifications and their position within the hollow spaces of the limestone. The spherules are arranged in the form of a chain. Their average diameter is $2 \mu \mathrm{m}$. The spherulites have been observed only in the hollow spaces and interfaces between the sediment grains.

Each spherulite contains many protrusions, which are approximately $0.3 \mu \mathrm{m}$ high. They are either rounded or sharp in the form of spines or they may have pyramid-like shapes. The spherulites themselves are irregularly rounded and some of them are partly replaced by rhombohedra of varying size, most probably of calcite.
The SEM micrographs of the spherulites as well as the walls of the hollow spaces around them show two types of crystalline change which probably are a product of diagenesis: (1) rhombohedra of calcite(?) which may have grown prior to the aragonite and may be large in comparison to the overgrowth described below; (2) extremely small, partly rounded crystallites forming a more or less continuous overgrowth on the spherulites and on parts of the walls. Although the crystal morphology of these crystallites is poorly developed, one may conclude that they consist of aragonite.

As to the interpretation of the spherulites, an inorganic origin as globular crystal aggregates cannot be completely excluded. However, they have a striking morphological similarity to sporangia of certain fungi, i.e., Actinomycetes such as in the genus Aspergillus described by Locci et al. (1972). The main difference of the forms described here from those described by Locci et al. (1972) is that each protuberance has a shape interpretable as a crystal habit, while the Recent forms are rounded and of entirely organic origin. The size of the spherulites described here is comparable in magnitude to those they described.

It may be concluded that the spherulites originated as sporangia of Actinomycetes and were later recrystallized by the formation of calcite rhombohedra and, possibly in a later stage of diagenesis, by a cryptocrystalline overgrowth (?aragonite). Although the formation of calcite crystallites and the overgrowth appears to be of the same age in the spherulites as on the walls, a very young origin of the spherulites cannot be completely excluded.

Clearly, the preservation of the extremely delicate spherulites has only become possible by crystallization of calcium carbonate, possibly in the diagenetic stage, and they may thus represent a truly fossil sporangium of an Actinomycete.

\section{ACKNOWLEDGMENTS}

The authors wish to thank $\mathrm{H}$. U. Nissen for valuable discussion.

\section{REFERENCE}

Locci, R. and Quaroni, S., 1972. Investigations on fungal features by scanning electron microscopy. V. Further studies on ascosporic Aspergillus species: Riv. Patolog. Vegetale, v. 8, p. 254-320. 


\section{PLATE 1}

Figure 1 Winding spherulite chain crossing spore space. Compare size with coccolith (arrow). (Bar $=5 \mu \mathrm{m}$.)

Figure 2 Spherulite chains within cavity. Compare cristallites grown on cavity wall with cristallites in Figure 3 (arrows). (Bar $=5 \mu \mathrm{m}$.)

Figure 3 Spherulite group with beginning overgrowth as orthorombic spines and rhombohedron (arrows). ( $\mathrm{Bar}=1$ $\mu \mathrm{m}$.

Figure 4 Spherulite cluster with progressive overgrowth. $($ Bar $=$ $1 \mu \mathrm{m}$.)

Figure 5 Detail of spherulite chain with starting overgrowth (large rhombohedrons). (Bar $=1 \mu \mathrm{m}$.)

Figure 6 Suggested accretion of cryptocristalline aragonite between the protrutions. $(\mathrm{Bar}=1 \mu \mathrm{m}$.) 
PLATE 1
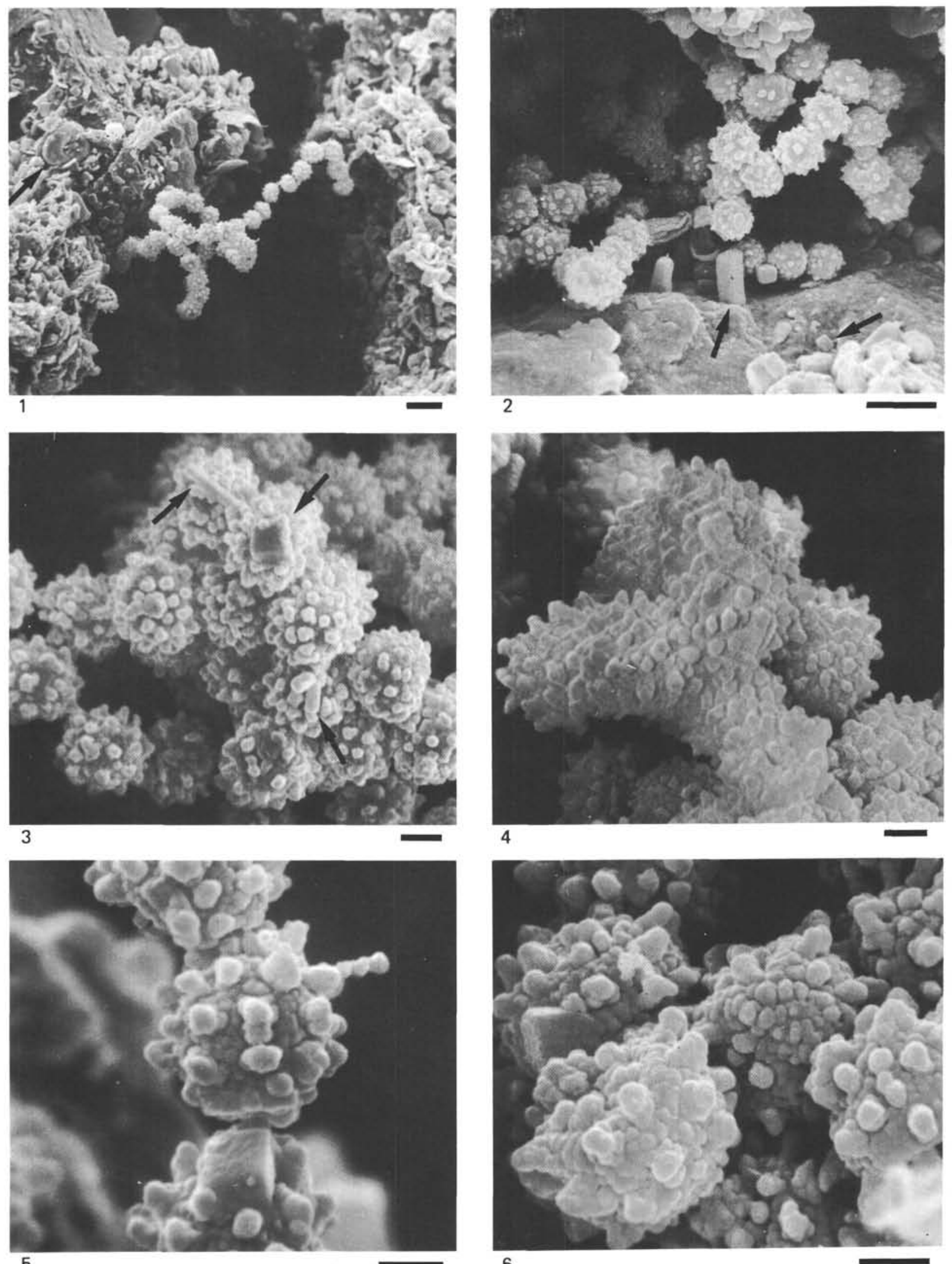